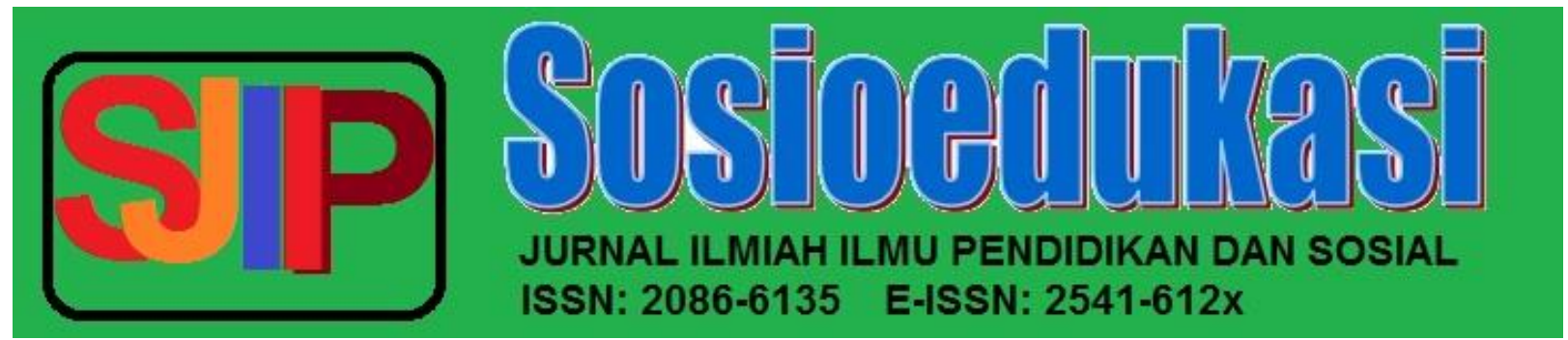

November Vol.9 No. 2 Tahun 2020 https://ejournal.unibabwi.ac.id/index.php/sosioedukasi/index

\title{
THE ROLE OF TEACHERS AND STUDENTS IN DEALING WITH EDUCATION IN THE PANDEMIC TIME OF COVID-19
}

\author{
Herrie Kurniawan \\ herriekurniawan131@gmail.com \\ SMAN 3 Babelan Bekasi
}

\section{ARTICLE HISTORY}

Received : $2310-2020$

Revised : 18-10-2020

Accepted : 17-11-2020

KEYWORDS

Education;

Teachers;

Students, Learning;

Online

\begin{abstract}
purpose of writing this article is to discuss the role of teachers and students in facing education during the Covid-19 pandemic. This writing method uses descriptive analysis method by reviewing the education system that occurred during the Covid-19 pandemic and seeing the role between teachers and students in facing the world of education during the Covid-19 pandemic. This descriptive analysis method will be collected and some reinforcing data will be provided for educational problems during the Covid-19 pandemic. The results of this writing will be useful in seeing how effective the education and learning system is for teachers and students in facing the Covid-19 pandemic and also whether education in Indonesia is ready to face the new learning system, especially for teachers and students who are facing online learning. during the Covid-19 pandemic.
\end{abstract}

This is an open access article under the CC-BY-SA license.

\section{INTRODUCTIONS}

The outbreak of Corona Virus Disease or what we often hear as Covid-19 which has hit more than 200 countries in the world, has had many impacts and challenges, especially in the field of education. In anticipating the transmission of the virus, the government has issued policies that are useful to reduce the spread of this virus, among others, such as isolation, social and physical distancing, to large-scale social restrictions or PSBB. With the conditions and policies that have been issued by the government, all existing activities are mostly carried out at home or the language that is often used at this time is stay at home. This condition causes the entire community to work, worship and study entirely at home.

This condition is what makes the government to change the overall conditions of learning and teaching in Indonesia by forming a new learning and teaching system with its innovation, 


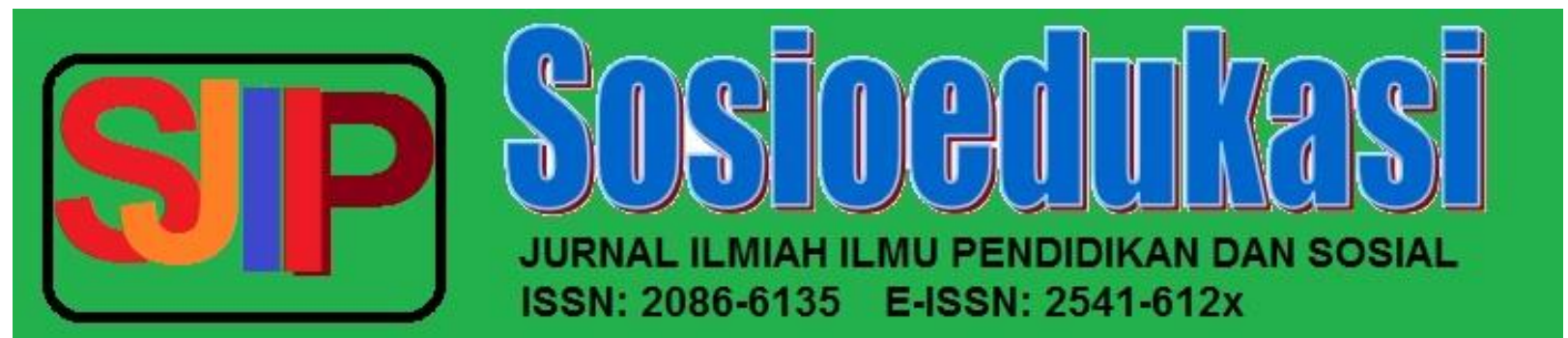

November Vol.9 No. 2 Tahun 2020

https://ejournal.unibabwi.ac.id/index.php/sosioedukasi/index

namely online orlearning online. However, each change will inevitably lead to pros and cons both on the part of the teacher and on the part of the students who will later carry out and carry out these online learning activities. Because it cannot be denied, according to the entire community education remains a very important priority for both parents

and children and because of the Covid-19 pandemic, the education system must change in line with its time and can no longer carry out the usual learning system with way at school.

Nadiem Makarim as the Minister of Education and Culture of Indonesia implemented a policy whereby online schools or home studies were conducted from mid-March 2020, for this policy there were many pros and cons for both students and teachers. Students who cannot attend school as usual will be taught online and done at home using the gadgets they have, but the first obstacle in this student is that not all students who already have gadgets are sophisticatedlike students in various big cities and it becomes a big question how with students who do not have sufficient economic capacity during this pandemic by buying internet quotas or buying gadgets they do not have. Teachers also have problems that are almost the same as students with limited gadgets, but especially for teachers who still find it difficult to open themselves to the internet will have difficulty with this online teaching and learning system because teachers have to adapt themselves to technology and the new internet and also requires teachers to present and provide both materials and assignments to students in accordance with existing learning materials.

As teachers and students who are the fulcrum for the progress of education in Indonesia, this is a challenge in the world of education, where this is the first time this has been done for several schools, where teachers and students at this time must be required to be independent with learning as well as education. The big obstacle to teachers and students is of course the detention of teachers and students at home will have a psychological effect that causes some teachers and students to stress because they are like being "imprisoned" at home and demanded to go to school at home. Seeing a situation like this, the government should study more deeply

by making a solution such as online learning with predetermined material but wrapped in the creativity of both the teacher or student so that the lesson is more enjoyable or can also reduce tasks that seem one-way in the process, such as the example. question and answer assignments from teacher to student and this assignment should be replaced such as making material by making videos at home or thinking maps that make teachers and students have updates in making assignments. 


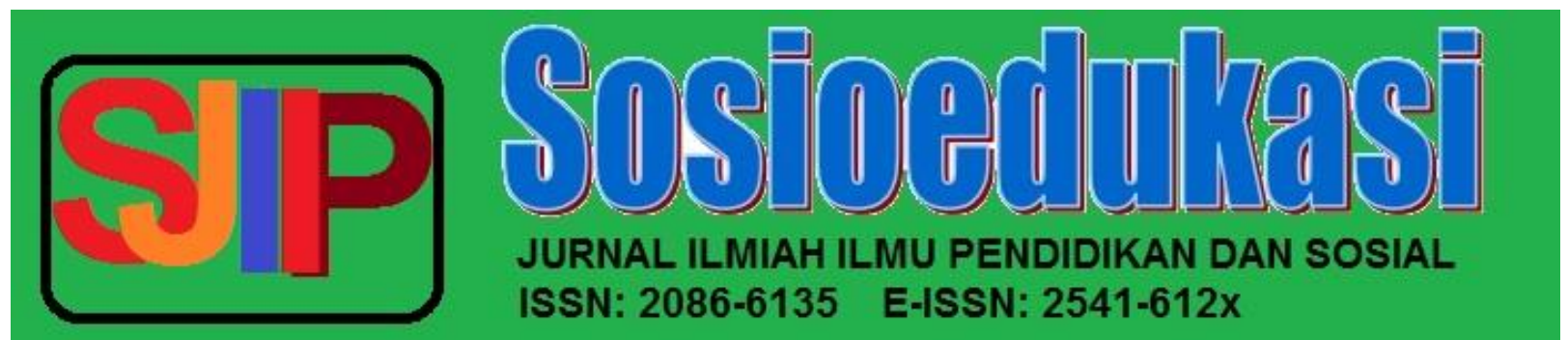

November Vol.9 No. 2 Tahun 2020

https://ejournal.unibabwi.ac.id/index.php/sosioedukasi/index

\section{MATERIALS AND METHODS RESEARCH LOCATION}

This research is a type of qualitative research. Qualitative research prioritizes the depth of appreciation of the interaction between concepts being studied empirically (Semi, 2012: 11). So that the results of qualitative research cannot be separated from the subjectivity of the researcher. As stated by Semiawan (2010: 7) that the results of qualitative research are strongly influenced by the views, thoughts and knowledge of researchers. The data in this study are primary data which are data obtained directly from the source (Siswantoro, 2005: 63). Primary data in this study were interviews with a number of informants, namely parents and students themselves. The reason for choosing both of them is that they are directly affected by policies related to the application of online-based learning methods during the pandemic, so that the reality that occurs is more valid to be tested for objectivity. In addition to interviews, primary data was obtained by observing a number of junior high school students who were affected by the application of learning methods during the pandemic. Then completed with literature study from reference sources related to theory, research methods, and other supporting written evidence. The data analysis technique used in this study is a qualitative descriptive technique with critical theory studies supported by the stages of child development in the rationalization of technology as a scalpel. This research was conducted at SMAS Nusantara Bungah, which has implemented-based learning methods online during the pandemic. However, the results of this study can be used as a broader critique of the learning model which of course has the same characteristics and systems as the research focus studied.

\section{RESULTS AND DISCUSSIONS}

\section{The role of teachers in education during the Covid-19 pandemic. A}

teacher who is someone who has a very important role in the world of education, where all teachers have a very noble duty and role. Apart from being teachers, teachers also serve as educators and second parents for their students at school. As a teacher as well as educator, the teacher must have the competence as a professional teacher. These competencies include pedagogical competence, personality, professional competence and social competence. The four competencies must be owned and fulfilled by a teacher because this can affect the success or failure of him in teaching. During this period the competence of a teacher will be tested, whether the teacher is competent in carrying out his duties or not. 


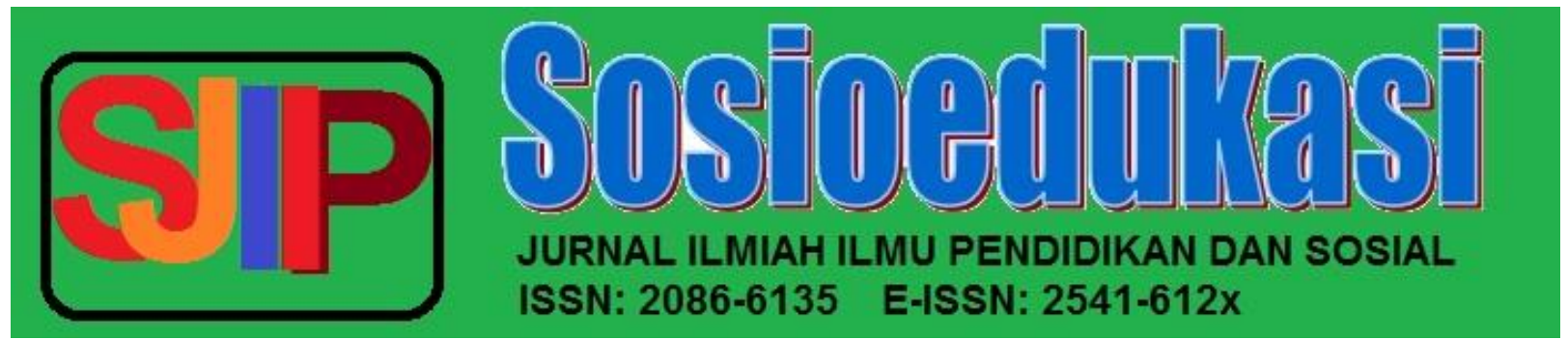

November Vol.9 No. 2 Tahun 2020 https://ejournal.unibabwi.ac.id/index.php/sosioedukasi/index

There are also demands for teacher competence apart from these four things, during the Covid-19 pandemic, many teachers are being charged with various demands, including:

1. the ability to innovate in teaching, utilize various digital software tools for teaching programs, conduct classes online, implementing a

2. curriculum that strengthens a multidisciplinary and collaborative model in teaching and learning.

3. Ability to rearrange accountability, determine methods in the assessment process.

4. The ability to provide education that helps students develop academically, physically and psychologically, by balancing "old" knowledge with digital mechanisms.

5. The ability to provide education and teaching equally, including for the most vulnerable.

6. Communication skills to synergize the views and vision of the child's education process with the principal, including parents / family.

These five demands become demands that will be faced by all teachers and become heroes and shields in education in Indonesia. In addition, the role of teachers during the Covid-19 pandemic includes:

1. Ensuring the achievement of educational goals and meeting academic and non-academic targets, preparing materials and learning evaluation results.

2. Teachers also have the responsibility of ensuring the safety of students physically and psychologically.

3. Provide active reinforcement and provide understanding to students to comply with all health protocols.

4. By continuing to prioritize facilitation of student learning, teachers must now always provide emotional support for students, parents, and families.

5. Teachers must be able to communicate and develop good cooperation with school principals,

parents / students' families to build trust and support the educational process. 1

In this extraordinary situation, teachers now have and are required to carry out many additional roles for which teachers should be given more wages, even during the Covid-19 pandemic. With the roles and demands above, we can find out some of the roles and demands made by teachers in the face of the Covid-19 pandemic. 


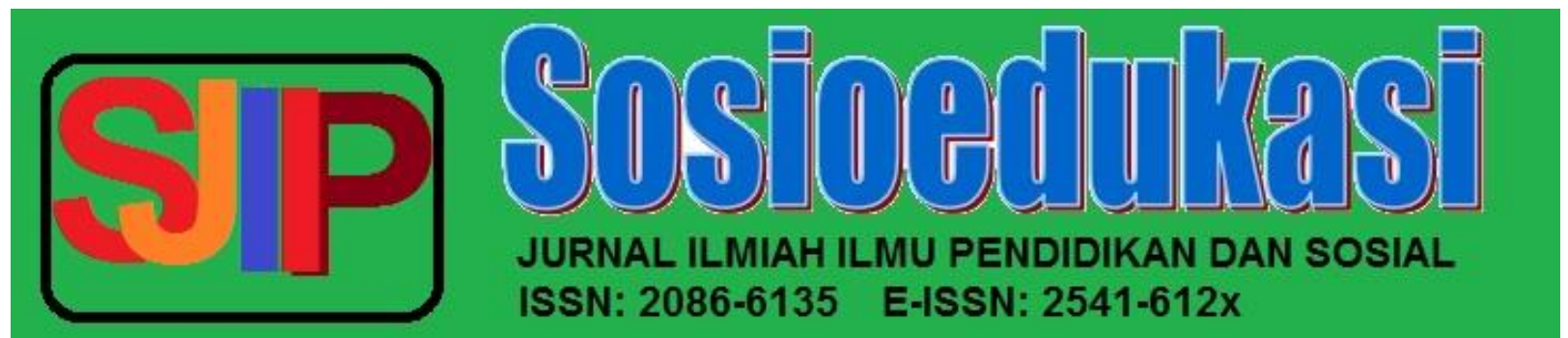

November Vol.9 No. 2 Tahun 2020 https://ejournal.unibabwi.ac.id/index.php/sosioedukasi/index

During the Covid-19 pandemic there were also some obstacles experienced by several teachers both in big cities and outside. Many of these obstacles are due to the lack of understanding by some teachers in using software and also sites and online learning room service providers on the internet. Some teachers must be required to learn to use the program, which for some teachers it is very unusual to use because it has never previously been used in existing learning methods in schools. Seeing this obstacle, it is time for teacher education to be prepared with any circumstances and a more advanced perspective in line with the era of technological developments that exist today.

\section{The role of students in education during the Covid-19 pandemic.}

Students are human components that occupy a central position in education or commonly known as learners. In the teaching and learning process, students as parties who want to complete the curriculum and in an effort to achieve goals or ideals. In the education law, students are the most important part

from the education system, so that the indicator of success or failure in the world of education is the success or failure of students after taking the educational process. The student or child is a "unique" person who has the potential and experiences a development process. In the process of developing, the child or student needs assistance whose character and style are not determined by the teacher but by the child himself, in a life together with other individuals. In the teaching-learning process, the first thing to pay attention to is the student / student, how are their conditions and abilities, then determine the other components. What materials are needed, what is the right way to act, what tools or facilities are suitable and supportive, all of which must be adapted to the circumstances / characteristics of the student. That is why pupils or students are learning subjects. 2

The role of students during the Covid-19 pandemic is very helpful with the development of education during the Covid 19 pandemic, where the support and success points of teachers will be tested through the students. During the Covid-19 pandemic, students should participate in obeying school regulations and try to be more active with learning media at this time and also prepare everything the school will need for learning for students. Students should also complete and collect assignments that will be given by the teacher in a timely manner. By following all school rules and following the teacher, students can carry out their role optimally to fight educational challenges. 


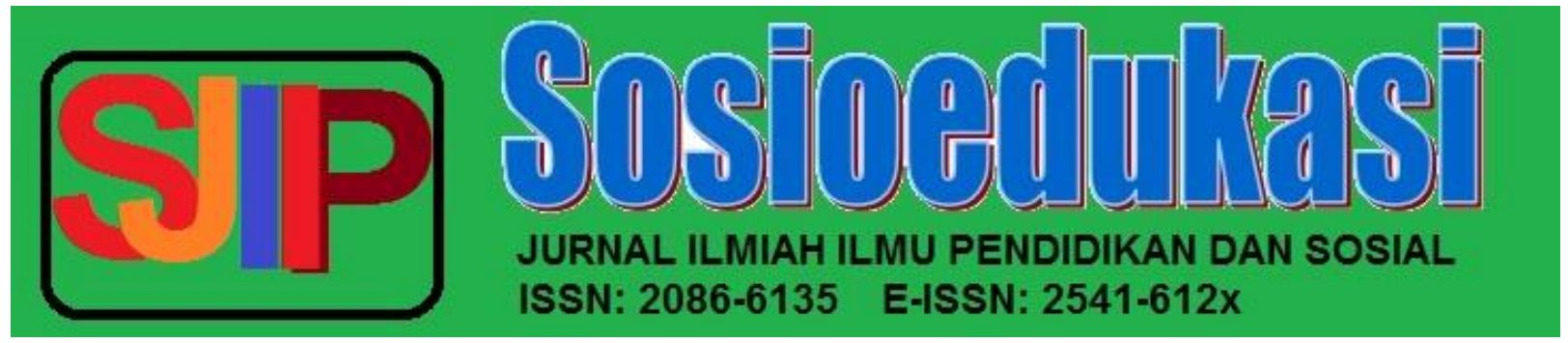

November Vol.9 No. 2 Tahun 2020 https://ejournal.unibabwi.ac.id/index.php/sosioedukasi/index

During the Covid-19 pandemic, all students are faced with the same problems as teachers, with various government policies that already exist, students are required to learn Many students have several obstacles, including:

1. Lack of Teacher Guidance

Lack of teacher guidance is the main obstacle in the Distance Learning (PJJ) system that was held during the Covid-19 pandemic. Of the total respondents surveyed by UNICEF in Public Perceptions of Covid-19, 38 percent of respondents said they lacked teacher guidance. This condition occurs because there is very little communication with the teacher during online learning. Learning using WhatsApp and learning applications from generally followed by many students with one teacher, so that the teacher cannot answer and provide opportunities for all students to ask questions, let alone convey the obstacles clearly.

2. Not Internet Access

SmoothThe most common complaint in the second place is that internet access is not smooth, which is acknowledged by 35 percent of respondents. Internet access is very much needed considering that around 60 percent of the media used by children to learn during the pandemic is the WhatsApp application, as many as 48 percent use online learning applications, as many as 31 percent of educational websites. Meanwhile, as many as 75 percent of children also use TV media and one percent radio.

3. Do not have a device

The third biggest obstacle is not having a device. Indeed, in terms of the presentation of children who do not have devices, it looks small, namely only 7 percent. However, if the number of students in Indonesia reaches 100 million, then there are 7 million children who cannot learn if the PJJ process requires gadgets or gadgets. This condition will certainly be very detrimental to the country because there are around 7 million young people who cannot learn during the Covid-19 pandemic. It is hoped that the negative impact of this condition will be reduced by the presence of subject matter broadcast via TV and radio. Other children try to stay able to learn online by borrowing from their parents, relatives, friends and neighbors, so that even if they don't have a device they can still learn.

4. Cannot Access Online Learning Applications 


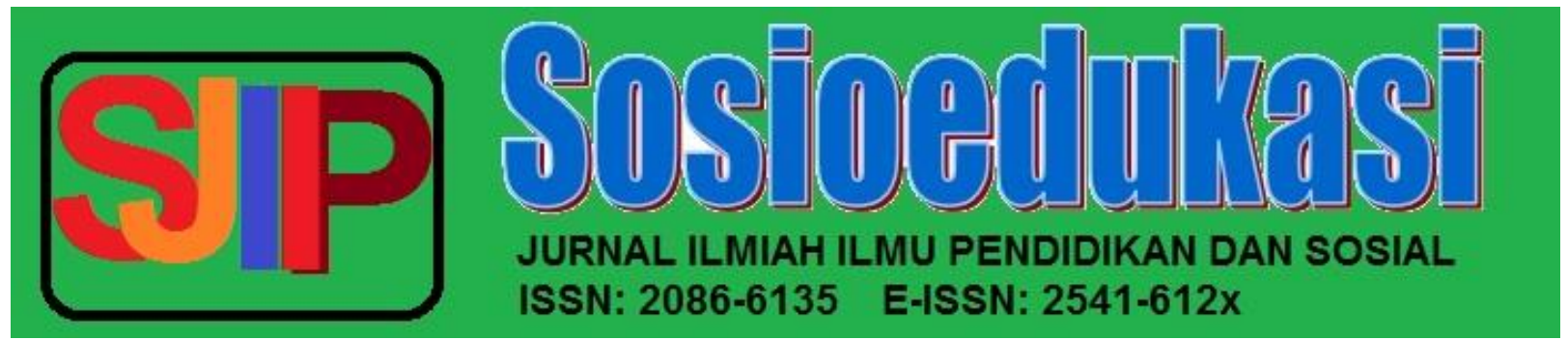

November Vol.9 No. 2 Tahun 2020 https://ejournal.unibabwi.ac.id/index.php/sosioedukasi/index

As many as 4 percent of children admit that they cannot access online learning applications. Children who are included in this group are children who do not have a device, but also cannot seek to borrow to be able to access online learning applications.

5. Lack of Parental Assistance The

fifth biggest obstacle to learning online is lack of parental guidance, which is 3 percent of the total respondents. This figure is also relatively large, given the very large population of Indonesia. Many parents are not ready to guide their children to study at school hours. Housewives have other activities during the day because they usually fully submit their children's education to schools. This condition causes a number of parents to start demanding the child's independence. Not to mention if there is more than one child in a family, so that the attention of parents can be divided. Meanwhile, as many as 13 respondents admitted to facing other obstacles, apart from the

four obstacles above for studying online at home during the Covid-19 pandemic. There is also a survey conducted by the Regional Child Protection Organizing Commission (KPPAD) regarding the learning process at home in an online system.

\section{Terlepas darl kerinduan dengan teman teman sekolah, Apakah pendapat adk-adlik proses belajar dirumah dalam slatem Daring? \\ 20.969 tangoapan}
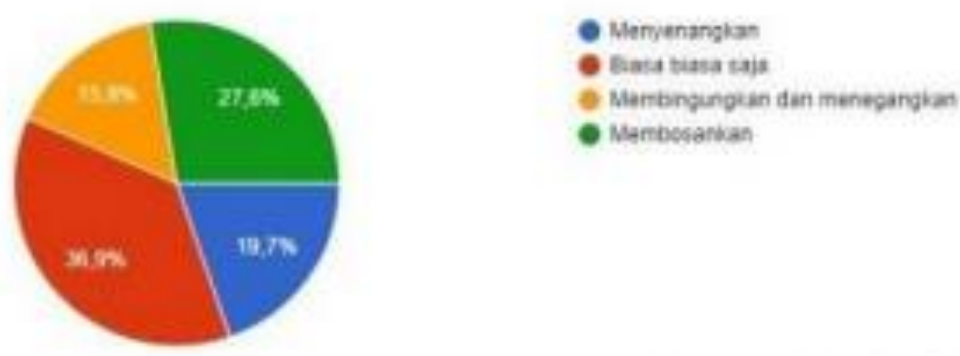

\section{CONCLUSION}

During the Covid-19 pandemic, we know how "panic" the education sector in Indonesia is in overcoming this problem, where the roles of teachers and students, which are very central to education, are still largely not ready to face the online learning that is currently being carried out. . With the system online learningonline learning, we can know that education must developing 


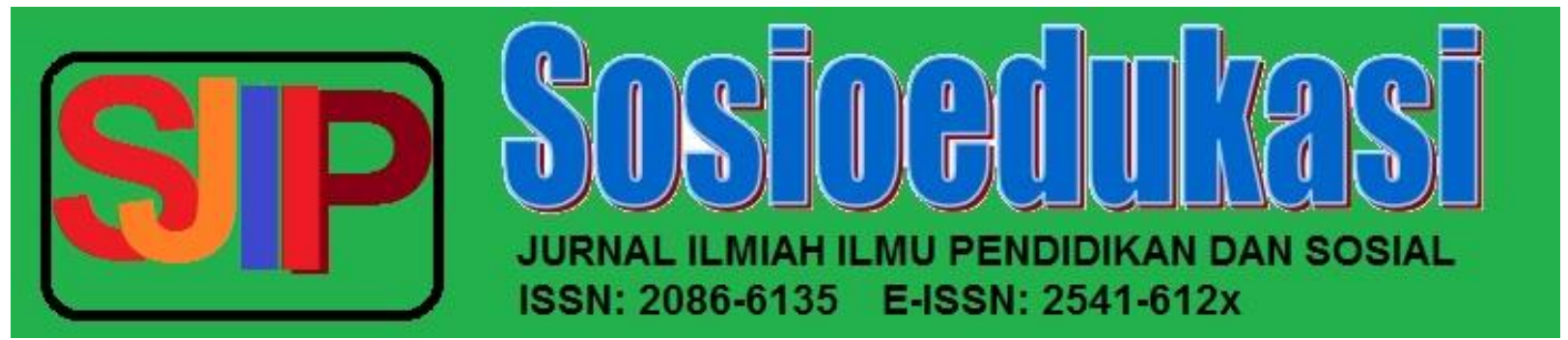

November Vol.9 No. 2 Tahun 2020 https://ejournal.unibabwi.ac.id/index.php/sosioedukasi/index

according to the times, especially for teachers and students by creating new and more innovative learning methods for the period after the Covid-19 pandemic.

Therefore, the role of teachers must be prepared for the new wave with the development of the world of education and prepare provisions to protect the world of education. The role of students is also very important, which will help teachers in advancing the world of education by mentally preparing for the current new education system and innovating existing learning actively in the education system.

\section{REFERENCES}

Adit, Albertus. (2020: 8 Oktober). Ini Peran dan Tuntutan Kompetensi Guru di Masa Pandemi. Diakeses pada 13 November 2020 melalui https://www.kompas.com/edu/read /2020/10/08/113530671/ini-peran-dan-tuntutan-kompetensi-guru-di-masapandemi?page=all\#: :text=Peran\%20guru\%20di\%20masa\%20pandemi\&text=Memastikan \%20tercapainya\%20tujuan\%20pendidikan\%20dan,didik\%20secara\%20fisik\%20dan\%20psi kis.

Muqqarobin, Firdaus. (2015: 5 Januari). Definisi Murid, Siswa dan Peserta Didik. Diakeses pada 13 November 2020 melalui https://eurekapendidikan.com/definisi-murid-siswa-dan-pesertadidik

Girsang, Erna. (2020: 29 Agustus). 5 Kendala Utama yang Dihadapi Siswa Selama Belajar Daring di Masa Pandemi. Diakeses pada 13 November 2020 melalui https://www.edoo.id/2020/08/29/5-kendala-utama-yang-dihadapi-siswa-selama-belajardaring-di-masa-pandemi/

Ramdhani, Muhammad Ali. (2014). Lingkungan Pendidikan dalam Implementasi Pendidikan Karakter. Garut: Jurnal Pendidikan Universitas Garut

Switri, Endang. 2019. Teknologi dan Media Pendidikan Dalam Pembelajaran. Pasuruan: Qiara Media 